Article

\title{
Prediction of Sporulation and Germination by the Spider Mite Pathogenic Fungus Neozygites floridana (Neozygitomycetes: Neozygitales: Neozygitaceae) Based on Temperature, Humidity and Time
}

\author{
Thiago Castro ${ }^{1,2}$, Rafael de Andrade Moral ${ }^{3}$ (D) , Clarice Garcia Borges Demétrio 4 (iD), \\ Italo Delalibera Jr. 1 (1) and Ingeborg Klingen ${ }^{5, *}$ \\ 1 Department of Entomology and Acarology; ESALQ-University of São Paulo (USP), Av Padua Dias, 11 P.O. \\ Box 9, 13418-900 Piracicaba, Brazil; delalibera@usp.br \\ 2 Koppert Biological Systems Brazil, Microbiology Product \& Development Department, Rodovia Margarida \\ da Graça Martins km 17,5 s/n (SP 135-Estrada Tupi), P.O. Box 35. 13400-970 Piracicaba SP, Brazil; \\ tcastro@koppert.com.br \\ 3 Department of Mathematics and Statistics, Maynooth University, Maynooth, W23 HW31 Co. Kildare, \\ Ireland; Rafael.DeAndradeMoral@mu.ie \\ 4 Department of Exact Sciences, ESALQ-University of São Paulo (USP), Av Padua Dias, 11 P.O. Box 9, \\ 13418-900 Piracicaba, Brazil; clarice.demetrio@usp.br \\ 5 Norwegian Institute of Bioeconomy Research (NIBIO), Division of Biotechnology and Plant Health, \\ Høgskoleveien 7, N-1431 Ås, Norway \\ * Correspondence: ingeborg.klingen@nibio.no; Tel.: +47-93-09-22-11
}

Received: 11 May 2018; Accepted: 14 June 2018; Published: 19 June 2018

\begin{abstract}
Neozygites floridana is a pathogenic fungus and natural enemy of the two-spotted spider mite, Tetranychus urticae (Acari: Tetranychidae), which is an important polyphagous plant pest. The aim of this study was to reveal and predict what combination of temperature, relative humidity $(\mathrm{RH})$, and time that enables and promotes primary conidia production and capilliconidia formation in N. floridana (Brazilian isolate ESALQ 1420), in both a detached leaf assay mimicking climatic conditions in the leaf boundary layer and in a semi-field experiment. In the detached leaf assay, a significant number of conidia were produced at $90 \%$ RH but the highest total number of primary conidia and proportion of capilliconidia was found at 95 and $100 \% \mathrm{RH}$ at $25^{\circ} \mathrm{C}$. Positive temperature and $\mathrm{RH}$ effects were observed and conidia production was highest in the 8 to $12 \mathrm{~h}$ interval. The semi-field experiment showed that for a $>90 \%$ probability of $N$. floridana sporulation, a minimum of $6 \mathrm{~h}$ with $\mathrm{RH}$ $>90 \%$ and $10 \mathrm{~h}$ with temperatures $>21^{\circ} \mathrm{C}$, or $6 \mathrm{~h}$ with temperatures $>21^{\circ} \mathrm{C}$ and $15 \mathrm{~h}$ with $\mathrm{RH}>90 \%$ was needed. Our study identified suitable conditions for primary- and capilliconidia production in this Brazilian N. floridana isolate. This information provides an important base for building models of a Decision Support System (DSS) where this natural enemy may be used as a tool in Integrated Pest Management (IPM) and a base for developing in vivo production systems of $N$. floridana.
\end{abstract}

Keywords: abiotic factors; microbial control; Tetranychidae; Entomophthorales; phytobiome; sporulation; integrated pest management (IPM); Decision Support System (DSS)

\section{Introduction}

The entomopathogenic fungal genus Neozygites belongs to the order Neozygitales in the class Neozygitomycetes in the phylum Entomophthoromycota [1]. Fungi in this genus infect small arthropods such as mealybugs, aphids, thrips, and mites [2,3]. Natural epizootics of Neozygites floridana have been documented in important mite pests of several major crops [4-11], including the two-spotted 
spider mite Tetranychus uricae (Acari: Tetranychidae), making the fungus an interesting candidate for conservation biological control [12]. However, the use of Neozygites in inundative or inoculative biological control is challenging, as Neozygites species are biotrophic (obligate pathogens) and are difficult to produce on artificial media [13]. These fungi have therefore only been produced by growing them on the host in small-scale in vivo cultures, even though it has been suggested that it would be possible to produce Neozygites on their host on a larger scale, dry the mummies, and store them at a low temperature for later application in inoculative or inundative biological control [14]. N. floridana and its related species develop inside spider mites as hyphal bodies, kill their host, penetrate the cuticle, and produce spores (primary conidia). Primary conidia are actively ejected from mite cadavers, referred to as mummies, and these conidia germinate to form the infective capilliconidia that infect new mites [15-17]. Environmental factors are known to regulate sporulation and germination of spores of entomopathogenic fungi within the Entomophthoromycota (e.g., [18]) and more specifically within the Neozygites (e.g., [19-23]). The ability of a pathogen to form high numbers of infective propagules is very important for the establishment, transmission, and successful epizootic development of the pathogen in a host mite or insect population [24]. One of the limitations for the utilization of N. floridana in biological control has been an incomplete understanding of how environmental factors such as relative humidity (RH), temperature, and light affect this [19]. Further, knowledge about optimal abiotic conditions required for $N$. floridana isolates from a specific region is lacking. In addition, the minimum time-period required at these optimal abiotic conditions for sporulation, germination, and infection of the mite to occur is also unknown.

Sporulation studies on microscope slides have shown that $\mathrm{RH}$ values greater than $95 \%$ and temperatures between 13 and $25{ }^{\circ} \mathrm{C}$ are critical for the reproduction of Neozygites spp. $[16,23,25,26]$. Studies on N. floridana pathogenic to Tetranychus evansi [23] and Tetranychus urticae [27] also suggest that the optimal sporulation temperature might vary substantially with the geographical origin of the isolate and the host species. The RH very close to the leaf (in the leaf-boundary layer), where spider mites are typically located, is dependent on leaf transpiration and is often higher than the ambient RH [28]. Macroclimatic conditions that appear to be too dry for mite and insect pathogenic fungi may therefore still provide sufficient humidity for the fungus to sporulate and establish in a host mite or insect population [29]. So far, no study has mimicked leaf-boundary layer conditions or characterized the minimum period of optimal RH and temperature needed for high levels of $N$. floridana primary conidia and capilliconidia production. In our study, we conducted a detached leaf assay mimicking leaf boundary layer conditions to explore (1) the numbers of $N$. floridana primary conidia and capilliconidia produced at four different RHs and temperatures; and (2) the time (hours (h)) at optimal RH- and temperature conditions required for production of a substantial number of $N$. floridana pirmary conidia and capilliconidia. Further, we conducted a semi-field screen house experiment on Jack bean plants where we investigated the correlation of temperature and RH measured in the screen house with the number of $N$. floridana primary conidia and capilliconidia produced.

\section{Material and Methods}

\subsection{Tetranychus urticae Stock Culture}

Tetranychus urticae was collected on Jack beans, Canavalia ensiformis (Fabales: Fabaceae), in Piracicaba in São Paulo state, Brazil $\left(22^{\circ} 44^{\prime} \mathrm{S}, 47^{\circ} 38^{\prime} \mathrm{W}\right)$ in 2009. A T. urticae stock culture was established and reared on Jack bean plants in $1 \mathrm{~L}$ plastic pots, in an acclimatized room at $25^{\circ} \mathrm{C}, 60 \%$ $\mathrm{RH}$, and $12 \mathrm{~h}$ of light. The plants were watered five times per week. Old and weak plants were replaced when required. 


\subsection{Neozygites floridana Isolate}

The Brazilian N. floridana isolate (ESALQ1420) used in these experiments was collected from T. urticae on Jack bean plants in Piracicaba, São Paulo state, Brazil $\left(22^{\circ} 44^{\prime}\right.$ S, $\left.47^{\circ} 38^{\prime} \mathrm{W}\right)$ in 2006. Duarte [30] confirmed species-level identification of the isolate using molecular methods.

\subsection{Cadaver Production}

Jack bean leaf discs ( $1.5 \mathrm{~cm}$ diameter) were placed abaxial side up on moistened cotton inside a Petri dish (5 cm in diameter and $2 \mathrm{~cm}$ high). Three non-sporulating but $N$. floridana-killed T. urticae cadavers were then placed on top of the leaf disc. The Petri dishes with cadavers on leaf discs were then placed inside a plastic box $(22 \times 16 \times 7 \mathrm{~cm})$ and incubated at $25 \pm 1{ }^{\circ} \mathrm{C}$ and $90 \% \mathrm{RH}$ for $24 \mathrm{~h}$, to induce sporulation from the cadavers. The boxes were covered with aluminum foil to ensure dark conditions for sporulation. After $24 \mathrm{~h}$, a compound microscope $(80 \times)$ was used to screen cadavers for sporulation, and only leaf discs with cadavers exhibiting good primary conidia and capilliconidia production were used further. Thirty uninfected adult T. urticae females were then transferred to each of the Petri dishes containing a leaf disk and three sporulating cadavers. The Petri dishes were then held at the conditions described above for $24 \mathrm{~h}$ to allow $N$. floridana infection of the life T. urticae. Petri dishes containing the $30 \mathrm{~N}$. floridana inoculated T. urticae on leaf discs were then kept at ambient laboratory conditions (21-28 ${ }^{\circ} \mathrm{C}, 20-35 \% \mathrm{RH}$ and $24 \mathrm{~h}$ of light) until the T. urticae were killed by N. floridana (8-9 days). During this period, the lid of the Petri dish was removed to maintain low RH so that T. urticae killed by $N$. floridana would not sporulate and rather develop into dry non-sporulating mummies. The cotton in the Petri dish was moistened as required to prevent the leaf disk from wilting. Dry, non-sporulating cadavers were collected from the leaf discs and stored at $-20{ }^{\circ} \mathrm{C}$ on dry cotton placed on top of blue silica gel (Dinâmica Ltda São Paulo-Brazil) in closed plastic vials (20 mL) for 10-15 days until start of experiment.

\subsection{Experimental Setup}

\subsubsection{Detached Leaf Assay: Temperature and RH Combinations}

To determine the optimal microclimatic temperature and RH for $N$. floridana primary conidia and capilliconidia production in a mimicked leaf-boundary layer situation, a detached Jack bean leaf assay was conducted inside a plastic chamber $\left(22.9 \times 21.3 \times 12 \mathrm{~cm}\right.$-Sanremo ${ }^{\circledR}$, Flower line $)$. The chambers contained $350 \mathrm{~mL}$ of a sulfuric acid solution at appropriate concentrations to obtain the targeted RHs as described by Solomon [31] and were placed in climatic chambers to obtain the desired temperatures (Figure 1). Five RH levels (80, 85, 90, 95 and 100\%) in combination with four temperature levels $\left(13,17,21\right.$ and $\left.25^{\circ} \mathrm{C}\right)$ were tested. Temperature levels were chosen based on the average yearly temperatures observed between 18:00 and 06:00 in Piracicaba, São Paulo, Brazil (http:/ / www.ler.esalq.usp.br/posto.html). A digital thermal hygrometer (Instrutherm-HT-500) was used inside the plastic chamber to confirm $\mathrm{RH}$ and temperature were accurate. Each experimental unit consisted of a Jack bean leaf with its petiole inserted into a $15 \mathrm{~mL}$ glass tube filled with distilled water and sealed with paraffin, to prevent the petiole from moving and evaporation of the water (Figure 1). Two N. floridana killed and mummified T. urticae females were placed on the abaxial side of each leaf. A photo-etched cover slip $(18 \times 18 \mathrm{~mm})$ with alphanumeric coded squares (Electron Microscopy Sciences, Hatfield, PA, USA) was placed $1 \mathrm{~cm}$ below the leaf and cadavers in order to collect conidia. The experimental unit was kept in darkness inside the chamber for $12 \mathrm{~h}$. Numbers of primary conidia and capilliconidia were counted on each photo-etched coverslip surface using a phase contrast microscope $(\times 400)$. Primary conidia that were in the process of forming or had already formed a capillary tube were defined as capilliconidia, all others were considered primary conidia. Five replicates of each $\mathrm{RH} \times$ temperature combination were performed yielding a total of 10 mummies per treatment and 160 mummies for the entire experiment. 


\subsubsection{Detached Leaf Assay: Minimum Period at Optimal Conditions for Sporulation}

To determine the minimum period (hours) needed at optimal $\mathrm{RH}$ and temperature conditions for substantial production of $N$. floridana primary conidia and capilliconidia, we used the same assay setup described above. Three humidity levels (90, 95, and 100\% RH) were used in combination with two temperature levels $\left(13^{\circ} \mathrm{C}\right.$ and $\left.25^{\circ} \mathrm{C}\right)$. Cadavers were exposed to these conditions for five different periods of time $(4,8,12,24$, and $36 \mathrm{~h})$. Four replicates of each $\mathrm{RH} \times$ temperature $\times$ duration combination yielded a total of 16 cadavers per combination and a total of 480 cadavers used in the experiment.

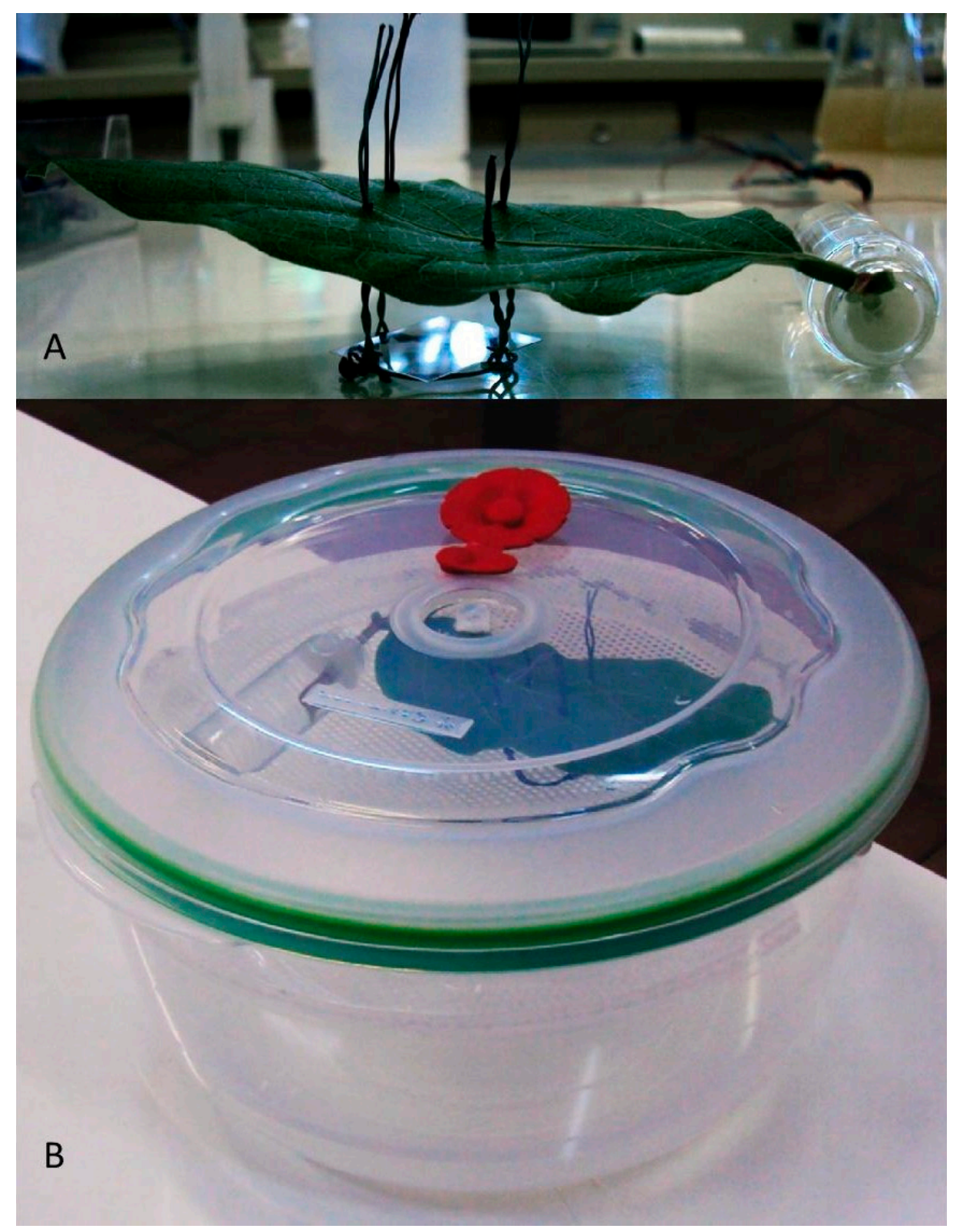

Figure 1. Detached Jack bean leaf assay setup (A) The experimental unit: Detached leaf placed above a photo-etched cover slip $(18 \times 18 \mathrm{~mm})$ with alphanumeric coded squares for collection and counting of conidia discharged from sporulating Neozygites floridana killed Tetranychus urticae cadavers placed on the underside of the leaf $(\mathbf{B})$ The experimental unit placed inside a plastic chamber $(22.9 \times 21.3 \times 12 \mathrm{~cm})$ providing controlled microclimatic conditions. 


\subsubsection{Semi-Field Screen House Experiment}

A screen house experiment was conducted to investigate the correlation between temperature and RH under semi-field conditions and the number of $N$. floridana primary conidia and capilliconidia produced. Five $N$. floridana killed and mummified T. urticae female mites were placed onto each of two leaves of a three-week old Jack bean plant once a week. Cadavers were placed on the underside of the leaf, near the central leaf vein, and at a distance of three $\mathrm{cm}$ from one another. To enable collection of conidia, leaves were taped to a plastic support with the abaxial side facing up. Plants were grown in $1 \mathrm{~L}$ plastic pots and the experiment was conducted from August 2010 to November 2011 in a screen house located at ESALQ-USP in Piracicaba, São Paulo, Brazil $\left(22^{\circ} 44^{\prime}\right.$ S, $\left.47^{\circ} 38^{\prime} \mathrm{W}\right)$. Leaves with mummies were destructively sampled from the plant $24 \mathrm{~h}$ after cadaver introduction. Primary conidia and capilliconidia produced was assessed by cutting out a leaf disc $2 \mathrm{~cm}$ in diameter around the cadaver. The cadaver was then removed and the leaf disc was placed on a glass slide under a microscope $(\times 100)$ the primary conidia and capilliconidia were counted using the same criteria described above. The light from the microscope made the leaf transparent but conidia visible. To facilitate large scale counting of conidia, we used a categorical scale as described by Wekesa [23] where high $>500$ conidia, low $>1$ and $<500$ conidia, and zero $=$ no conidia. $\mathrm{RH}$ and temperature data were recorded using a data logger (HT-500, Instrutherm-São Paulo, Brazil) located close to a Jack bean leaf inside the screenhouse.

\subsection{Statistical Analysis}

The statistical analyses were based on the theory of generalized linear models and extensions [32]. All analyses were carried out in R, using the "stats" package [33]. Half-normal plots with simulation envelopes were used to assess goodness-of-fit of the fitted models, using the package "hnp" [34].

\subsubsection{Detached Leaf Assays: Temperature, $\mathrm{RH}$, and Duration}

Number of Primary Conidia and Capilliconidia, Total Number of Conidia, and Proportion of Capilliconidia

Quasi-Poisson generalized linear models were fitted to the count data, with different intercepts and slopes over temperature per RH level. Quasi-binomial generalized linear models were fitted to the proportion of germinated conidia out of total number of produced conidia (primary conidia + capilliconidia), with different intercepts and slopes over temperature per RH level. Nested models were also fitted to the data and F-tests were performed to assess the significance of the effects.

\subsubsection{Semi-Field Screen House Experiment}

A quasi-binomial generalized linear model was fitted to the proportion of cadavers that sporulated (scored as "low" or "high" sporulation based on the categorical scale described above) including a response surface for the time spent (in hours) at RH higher than $90 \%$ and temperature higher than $21^{\circ} \mathrm{C}$.

\section{Analyses for Experiment Considering Duration}

For the total number of conidia (primary conidia + capilliconidia), as well as number of primary conidia and capilliconidia, quasi-Poisson generalized linear models were fitted with different linear predictors per each temperature $\times \mathrm{RH}$ combination, with a segmented regression over time. The breakpoint of the segmented regression was estimated by maximizing the profile-likelihood of a Poisson model fitted using the maximal linear predictor described above. Nested models were also fitted to the data and F-tests were performed to assess the significance of the effects. 
Goodness-of-Fit Assessment and Software

Half-normal plots with simulation envelopes were used to assess goodness-of-fit of the fitted models, using package "hnp" [34]. All analyses were carried out in R, using the "stats" package [33].

\section{Results}

\subsection{Detached Leaf Assay: Temperature and RH Combinations}

Figure 2A demonstrates that the highest number of conidia (primary conidia and capilliconidia) was produced at $95 \%$ and $100 \% \mathrm{RH}$ at $25{ }^{\circ} \mathrm{C}$. Also, at 13,17 , and $21{ }^{\circ} \mathrm{C}$ the number of primary conidia and capilliconidia produced was significantly $\left(\mathrm{F}_{2,114}=4.74, p=0.0106\right)$ higher at $\geq 95 \% \mathrm{RH}$ than $\leq 90 \%$ RH. Further, a significant $\left(\mathrm{F}_{1,118}=59.21, p<0.0001\right)$ positive temperature effect on total conidia production was seen for all temperatures at $\geq 90 \% \mathrm{RH}$ (Figure $2 \mathrm{~A}$ ). Figure $2 \mathrm{~B}$ suggests that the highest proportion of capilliconidia was produced at $\geq 95 \% \mathrm{RH}$ at $25^{\circ} \mathrm{C}$. The same trend occurred at lower temperatures $\left(13,17\right.$, and $\left.21^{\circ} \mathrm{C}\right)$, with $\geq 95 \% \mathrm{RH}$ resulting in a significantly $\left(\mathrm{F}_{2,86}=12.83\right.$, $p<0.0001$ ) higher proportion of capilliconidia produced compared to lower RHs. Further, a significant $\left(\mathrm{F}_{1,90}=31.36, p<0.0001\right)$ positive temperature effect on proportion of capilliconidia produced was seen for all temperatures at $\geq 95 \%$ RH (Figure 2B). Capilliconidia production was influenced more by $\mathrm{RH}$ than primary conidia production, and at $90 \% \mathrm{RH}$, an increase in capilliconidia production with increased temperature was not observed even though it was observed for primary conidia (Figure 2A,B). No sporulation occurred at any temperature when $\mathrm{RH}$ was $\leq 85 \%$ (Figure $2 \mathrm{~A}$ ).
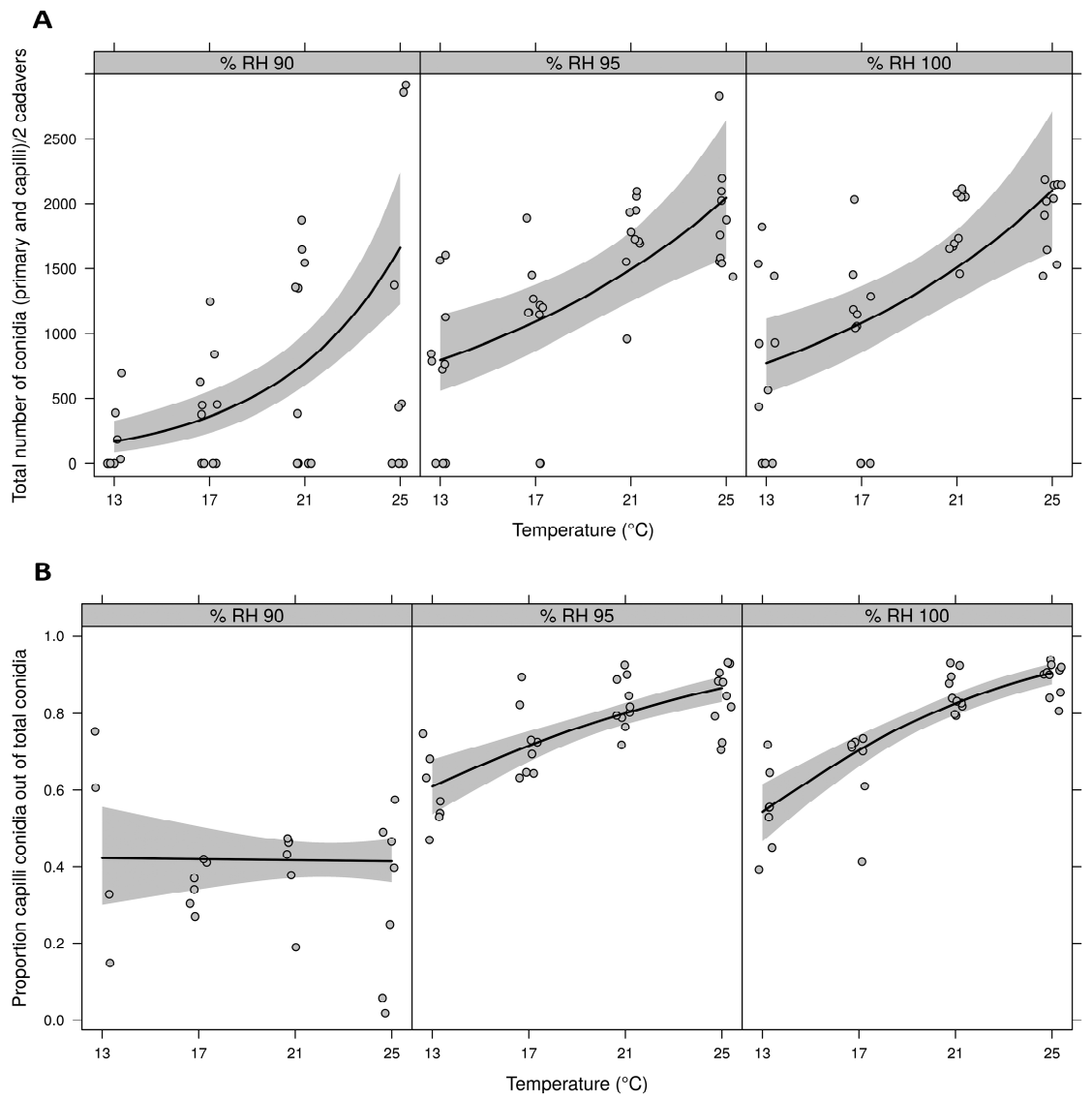

Figure 2. Effect of relative humidity (RH) $(80,85,90,95,100 \%)$ and temperature $\left(13,17,21\right.$, and $\left.25{ }^{\circ} \mathrm{C}\right)$ on (A) Mean total number of conidia (primary conidia and capilliconidia)/cadaver for a Brazilian Neozygites floridana isolate (ESALQ 1420) (B) Proportion of Neozygites floridana capilliconidia out of the total number of conidia. $\mathrm{RH} 80 \%$ and $85 \%$ not shown, as no sporulation was detected. 


\subsection{Detached Leaf Assay: Minimum Period for Optimal RH and Temperature}

Almost all primary conidia were discharged between 8 and $12 \mathrm{~h}$ (estimated breakpoint for the segmented regressions) for all combinations of environmental factors tested (Figure 3A). For primary conidia there was a significant interaction between $\mathrm{RH}$ and temperature $\left(\mathrm{F}_{2,112}=33.15, p<0.0001\right)$, showing that all curves were different, except for the temperature $25{ }^{\circ} \mathrm{C}$, where $95 \% \mathrm{RH}$ and $100 \%$ $\mathrm{RH}$ are statistically equal $\left(\mathrm{F}_{1,113}=0.79, p=0.3751\right)$ (Figure $\left.3 \mathrm{~A}\right)$. Capilliconidia formation was also observed only between 8 and $12 \mathrm{~h}$ for all combinations of environmental factors tested (Figure 3B). For capilliconidia there was a significant interaction between $\mathrm{RH}$ and temperature $\left(\mathrm{F}_{2,112}=6.06\right.$, $p=0.0032$ ), except for at 95\% RH and $100 \% \mathrm{RH}$ which independent of the temperature, were equal $\left(\mathrm{F}_{2,112}=2.10, p=0.1267\right)$ (Figure $\left.3 \mathrm{~B}\right)$. After 12,24 , and $36 \mathrm{~h}$ at $25^{\circ} \mathrm{C}$, a higher number of primary conidia was observed at 90\% RH compared to $95 \%$ and $100 \%$ RH (Figure 3A) while for capilliconidia, a lower number was observed at $90 \% \mathrm{RH}$ compared to $95 \%$ and $100 \% \mathrm{RH}$ (Figure $2 \mathrm{~B}$ ). At $13{ }^{\circ} \mathrm{C}$, formation of capilliconidia from primary conidia was close to zero (Figure 3B). Further, no sporulation was observed from mummified mites during the first $4 \mathrm{~h}$ or after $12 \mathrm{~h}$ for any of the environmental conditions tested (Figure 3A).
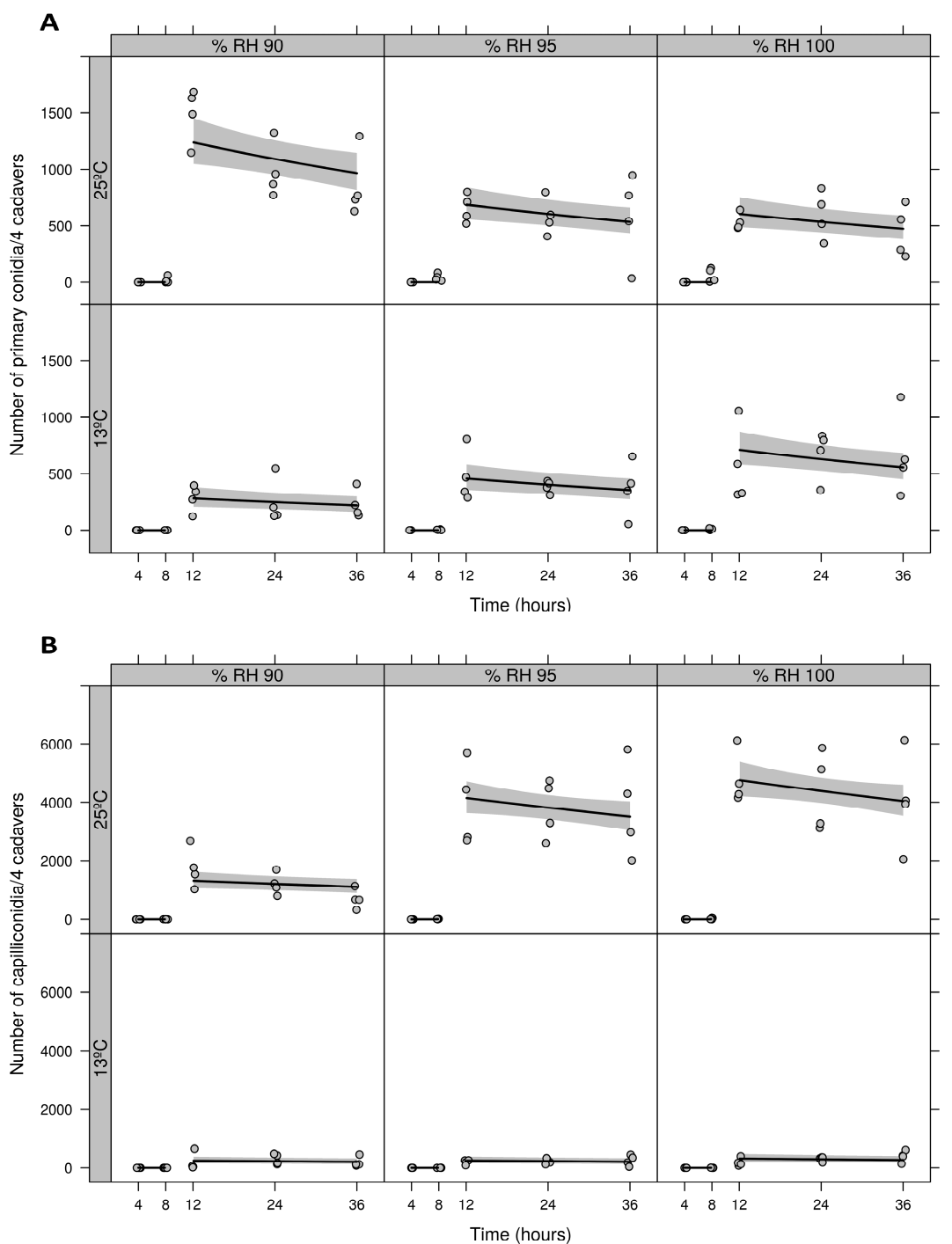

Figure 3. Effect of time $(4,8,12,24$ or $36 \mathrm{~h})$ on primary conidia production (A) and capilliconidia formation (B) by a Brazilian Neozygites floridana isolate (ESALQ 1420) at three different RHs (90, 95, $100 \%)$ and two temperatures $\left(13,25^{\circ} \mathrm{C}\right)$. 


\subsection{Semi-Field Screen House Experiment}

The screen house semi-field experiment showed a clear positive correlation between number of hours with $\mathrm{RH}>90 \%$ and number of hours with temperatures $>21^{\circ} \mathrm{C}$ and when a combination of both these factors were present, a higher sporulation of the Brazilian N. floridana isolate tested occurred. For $>90 \%$ probability of $N$. floridana sporulation, a minimum of $6 \mathrm{~h}$ with $\mathrm{RH}>90 \%\left(\mathrm{~F}_{1,25}=12.97\right.$, $p=0.0014)$ and $10 \mathrm{~h}$ with temperatures $>21{ }^{\circ} \mathrm{C}\left(\mathrm{F}_{1,26}=9.36, p=0.0054\right)$, or a minimum of $6 \mathrm{~h}$ with temperatures $>21{ }^{\circ} \mathrm{C}$ and $15 \mathrm{~h}$ with $\mathrm{RH}>90 \%$ (Interaction: $\mathrm{F}_{1,24}=9.17, p=0.0058$ ), was needed (Figure 4).

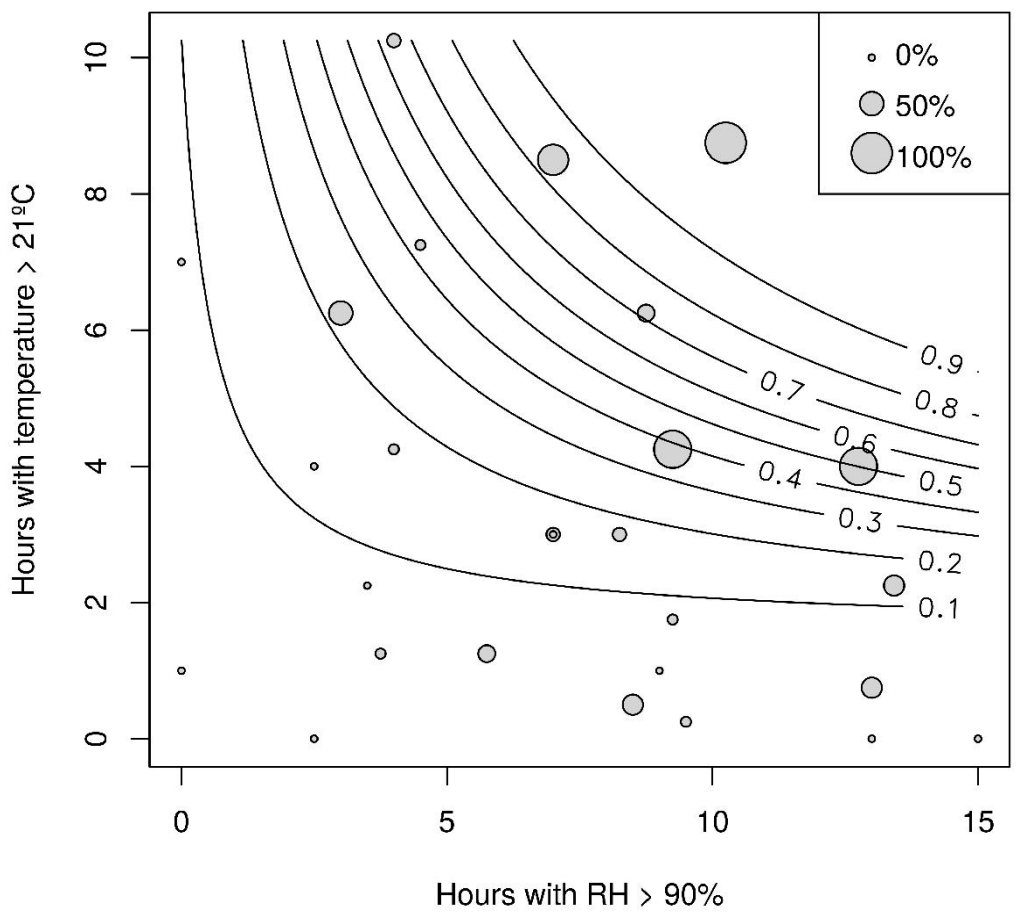

Figure 4. Combined effect of temperature and RH on sporulation of a Brazilian Neozygites floridana isolate (ESALQ 1420) from Tetranychus urticae cadavers on Jack beans in a semi-field screen house study in Piracicaba, São Paulo, Brazil, from August 2010 to November 2011. Point size is scaled by the percentage of cadavers sporulating and the lines represent the probability of sporulation from 0.1 to 0.9 (10\% to $90 \%$ ).

\section{Discussion}

Under the leaf-boundary layer climatic conditions mimicked in our detached leaf assay we found that the Brazilian N. floridana isolate sporulated at $90 \% \mathrm{RH}$ and that, at $25{ }^{\circ} \mathrm{C}$, no difference in the number of primary conidia and capilliconidia produced was observed between $95 \%$ and $100 \%$ $\mathrm{RH}$. Previous studies aiming to determine the temperature and $\mathrm{RH}$ requirement for sporulation of Neozygites spp. were carried out on microscope slides and have shown that RH values greater than $95 \%(100 \%$ being the best $\mathrm{RH})$ and temperatures between 13 and $27{ }^{\circ} \mathrm{C}$ are critical for fungal reproduction $[16,23,25,26,35]$.

The optimal temperature for conidia production found here concurs with the optimal temperature $25{ }^{\circ} \mathrm{C}$ that Wekesa [23] found for two Brazilian N. floridana isolates on T. evansi (ESALQ 1419 and ESALQ 1421) tested at 13, 17, 21, 25, 29, and $33^{\circ} \mathrm{C}$. It is, however, higher compared to the optimal temperature of $18{ }^{\circ} \mathrm{C}$ found for a Norwegian $N$. floridana isolate on T. urticae (NCRI 271/04) tested at 13,18 , and $23^{\circ} \mathrm{C}$ [27]. Neither Wekesa [23] nor Klingen and Nilsen [27] tested the effect of different RH levels. Smitley et al. [35] report that, when testing numbers of primary conidia produced by a N. floridana isolate (host T. urticae) from Chowan, North Carolina, USA at 4, 10, 16, 21, 27, 29, 
and $32{ }^{\circ} \mathrm{C}$ and $75 \%, 85 \%, 98 \%$, and $100 \% \mathrm{RH}$, the temperature optimum was $21{ }^{\circ} \mathrm{C}$ at $100 \% \mathrm{RH}$. A significant number of primary conidia was also produced at $98 \%$ RH but not at 75 or $85 \% \mathrm{RH}$. Smitley et al. [35] also report that temperature and $\mathrm{RH}$ requirements for the formation of capilliconidia were similar for the production of primary conidia. Our studies suggest, however, that capilliconidia production was more influenced by RH than primary conidia production. Therefore, further detailed study is needed to fully understand the effect of abiotic factors and mechanisms by which they impact primary conidia and capilliconidia production in this fungus. Brown and Hasibuan [25] also report that the highest number of $N$. floridana conidia produced (not distinguishing between conidial type) on T. urticae (fungus and host originating from North Carolina) were at $100 \%$ RH when compared to $90 \%$ and $80 \%$ RH. In addition, studies conducted with Neozygites tanajoae (earlier named N. floridana) on Mononychellus tanajoa (e.g., [16,36,37]) suggest that RH levels above $96 \%$ were needed before primary conidia production occurred.

When comparing different studies with $N$. floridana we suggest that the optimal temperature varies depending on the geographic, and hence climatic, origin of the isolate tested. It ranges from $18^{\circ} \mathrm{C}$ for isolate from a northern location like Ås, Norway $\left(59^{\circ} 39^{\prime \prime} \mathrm{N}, 10^{\circ} 46^{\prime} \mathrm{W}\right)$ through $21^{\circ} \mathrm{C}$ for isolate from a temperate location like Chowan, North Carolina, USA $\left(38^{\circ} 07^{\prime \prime} \mathrm{N}, 76^{\circ} 35^{\prime} \mathrm{W}\right)$ to $27^{\circ} \mathrm{C}$ from a tropical location like Piracicaba, São Paulo, Brazil $\left(22^{\circ} 44^{\prime} \mathrm{S}, 47^{\circ} 38^{\prime} \mathrm{W}\right)$ in this study. The average temperature during the growth season for these three locations is in the same range as the optimum temperature for the fungus. We therefore suggest that to be able to build good descriptive models for this pest natural enemy system it is imperative to include knowledge about the temperature in the region where the isolate come from. The optimal RH levels are more similar for all geographical origins, however, and close to $100 \%$. In our detached leaf assay mimicking leaf boundary climatic conditions, sporulation was found at ambient $\mathrm{RH}$ conditions of $90 \%$ which is lower than what has been found in laboratory studies measuring sporulation on microscopic slides. This may suggest that the humidity in the microclimate close to leaf surface (in the leaf boundary layer) in our study was higher and that this might have contributed to the primary conidia production. Tomato greenhouse studies with fungi in the Hypocreales support that a higher humidity is found in the leaf boundary layer and that this benefits microbial control of small arthropod pests, such as T. urticae, living in the leaf boundary layer [28,29,38].

In the laboratory time series assay, almost all primary conidia were discharged and most capilliconidia formed between 8 and $12 \mathrm{~h}$ under the environmental factors tested (RH and temperature). Our screen house semi-field experiment with the same Brazilian N. floridana isolate confirms the findings from our assays mimicking leaf-boundary climatic conditions. This provides preliminary evidence that our calculated optima can be applied in natural field settings, but further experimental field data is required to confirm this. Further, our screen house semi-field experiment that indicates the duration of the period with optimal RH level and temperature is also relevant to conidia production. A clear positive correlation was observed between a combination of number of hours (minimum $6 \mathrm{~h}$ ) with $\mathrm{RH}>90 \%$ and number of hours (minimum $10 \mathrm{~h}$ ) with temperatures $>21^{\circ} \mathrm{C}$ for high sporulation. As such, the duration of periods within the temperature and $\mathrm{RH}$ optimal ranges should be included when building a descriptive model for this pest natural enemy system.

This study identifies both temperature and RH optima for conidia production in N. floridana, as well as suggesting the minimum duration of these conditions needed to result in significant sporulation. It is important, however, to note the limitations for the implications of the results from one isolate to another isolate, as the optimal temperature for conidiation in N. floridana varies and seems to be linked to the geographical and climatic origin of the isolate. This needs to be taken into consideration when carefully making descriptive models for the potential epidemic development for the fungus in a specific host pathogen system in a specific climatic region (e.g., tropical or temperate) or production system (e.g., field or greenhouse). Detailed characterization of the abiotic factors affecting reproduction of insect pathogens provide an important base for building descriptive models with potential to be further developed, validated, and used in a Decision Support System (DSS) for the use of this natural 
enemy as a tool in Integrated Pest Management (IPM). The data presented here also provides a basis that could be used for establishing an in vivo biocontrol agent production system for $N$. floridana.

\section{Conclusions}

Significant number of conidia were produced at $90 \%$ RH but the highest total number of primary conidia and proportion of capilliconidia was found at 95 and $100 \% \mathrm{RH}$ at $25^{\circ} \mathrm{C}$. Most conidia were produced between 8 and $12 \mathrm{~h}$. Based on the semi-field experiment it is predicted that there was $90 \%$ probability for $\mathrm{N}$. floridana sporulation to occur, with a minimum of $6 \mathrm{~h}$ with $\mathrm{RH}>90 \%$ and $10 \mathrm{~h}$ with temperatures $>21{ }^{\circ} \mathrm{C}$; or $6 \mathrm{~h}$ with temperatures $>21^{\circ} \mathrm{C}$ and $15 \mathrm{~h}$ with $\mathrm{RH}>90 \%$ needed. This information provides an important base for building models of a pest natural enemy Decision Support System (DSS) and for developing in vivo production systems for N. floridana.

Author Contributions: Conceptualization: I.D.J., I.K. and T.C. Methodology: I.D.J., I.K. and T.C. Software: R.d.A.M. Validation: T.C. Formal Analysis: R.d.A.M. and C.G.B.D. Investigation: T.C. Resources: I.D.J. and I.K. Data Curation: T.C. and R.d.A.M. Writing-Original Draft Preparation: T.C. Writing-Review \& Editing: I.D.J., I.K, T.C. and R.d.A.M. Supervision: C.G.B.D.; I.D.J. and I.K. Project Administration: I.D.J. and I.K. Funding Acquisition: I.D.J. and I.K.

Funding: Norges Forskningsråd: 244526. Conselho Nacional de Desenvolvimento Científico e Tecnológico: 479201/2008 0. Fundação de Amparo à Pesquisa do Estado de São Paulo: 2007/07805-3 and 2008/07358-0.

Acknowledgments: This research was funded by the Norwegian Foundation for Research Levy on Agricultural Products (FFL) and the Agricultural Agreement Research Funds (JA) through the project BERRYSYS (project number 190407) and The Research Council of Norway through the SMARTCROP project (project number 244526). The Brazilian National Council for Scientific and Technological Development (CNPq—project number 479201/2008 0). The first author was a recipient of scholarships from the São Paulo Research Foundation (FAPESP, project number 2007/07805-3 and 2008/07358-0). We thank Marie Louise Davey at NIBIO for revising the English and also for other valuable comments. Finally, we thank three anonymous reviewers for many useful comments and suggestions, which helped improving the manuscript.

Conflicts of Interest: The authors declare no conflict of interest.

\section{References}

1. Humber, R.A. Entomophthoromycota: A new phylum and reclassification for entomophthoroid fungi. Mycotaxon 2012, 120, 477-492. [CrossRef]

2. Keller, S. Entomophthorales of Switzerland. II. Erynia, Eryniopsis, Neozygites, Zoophthora and Tarichium. Sydowia 1991, 43, 39-112.

3. Keller, S. The genus Neozygites (Zygomycetes, Entomophthorales) with special reference to species found in tropical regions. Sydowia 1997, 49, 118-146.

4. $\quad$ Duarte, V.S.; Silva, R.A.; Wekesa, V.W.; Rizzato, F.B.; Dias, C.T.S.; Delalibera, I., Jr. Impact of natural epizootics of the fungal pathogen Neozygites floridana (zygomycetes: Entomophthorales) on population dynamics of Tetranychus evansi (acari: Tetranychidae) in tomato and nightshade. Biol. Control 2009, 51, 81-90. [CrossRef]

5. Humber, R.A.; Moraes, G.J.; Dossantos, J.M. Natural infection of Tetranychus evansi [acarina, tetranychidae] by a triplosporium sp. [zygomycetes, entomophthorales] in northeastern brazil. Entomophaga 1981, 26, 421-425. [CrossRef]

6. Klubertanz, T.H.; Pedigo, L.P.; Carlson, R.E. Impact of fungal epizootics on the biology and management of the twospotted spider mite (acari: Tetranychidae) in soybean. Environ. Entomol. 1991, 20, 731-735. [CrossRef]

7. Boykin, L.S.; Campbell, W.V.; Beute, M.K. Effect of pesticides on Neozygites floridana (entomophthorales: Entomophthoraceae) and arthropod predators attacking the twospotted spider mite (acari: Tetranychidae) in north-carolina peanut fields. J. Econ. Entomol. 1984, 77, 969-975. [CrossRef]

8. Carner, G.R.; Canerday, T.D. Entomophthora sp. As a factor in regulation of twospotted spider mite in cotton. J. Econ. Entomol. 1970, 63, 638-640. [CrossRef]

9. Smitley, D.R.; Kennedy, G.G.; Brooks, W.M. Role of the entomogenous fungus, Neozygites floridana, in population declines of the twospotted spider mite, Tetranychus urticae, on field corn. Entomol. Exp. Appl. 1986, 41, 255-264. [CrossRef]

10. Mietkiewski, R.; Balazy, S.; Van der Geest, L.P.S. Observations on a mycosis of spider-mites (acari, tetranychidae) caused by Neozygites floridana in poland. J. Invertebr. Pathol. 1993, 61, 317-319. [CrossRef] 
11. Nordengen, I.; Klingen, I. Comparison of methods for estimating the prevalence of Neozygites floridana in Tetranychus urticae populations infesting strawberries. J. Invertebr. Pathol. 2006, 92, 1-6. [CrossRef] [PubMed]

12. Van der Geest, L.P.; Elliot, S.L.; Breeuwer, J.A.; Beerling, E.A. Diseases of mites. Exp. Appl. Acarol. 2000, 24, 497-560. [CrossRef] [PubMed]

13. Delalibera, I., Jr.; Hajek, A.E.; Humber, R.A. Use of cell culture media for cultivation of the mite pathogenic fungi Neozygites tanajoae and Neozygites floridana. J. Invertebr. Pathol. 2003, 84, 119-127. [CrossRef] [PubMed]

14. Kennedy, G.G.; Smitley, D.R. Method of Controlling Plant Feeding Mites with the Fungus Neozygites floridana. U.S. Patent No 4,752,468, 21 June 1988.

15. Carner, G.R. A description of the life cycle of Entomophthora sp. in the two-spotted spider mite. J. Invertebr. Pathol. 1976, 28, 245-254. [CrossRef]

16. Delalibera, I., Jr.; Demétrio, C.G.B.; Manly, B.F.J.; Hajek, A.E. Effect of relative humidity and origin of isolates of Neozygites tanajoae (zygomycetes: Entomophthorales) on production of conidia from cassava green mite, Mononychellus tanajoa (acari: Tetranychidae), cadavers. Biol. Control 2006, 39, 489-496. [CrossRef]

17. Elliot, S.L. Ecology and Epizootiology of Neozygite floridana, a Pathogen of the Cassava Green Mite; Imperial College: London, UK, 1998.

18. Pell, J.K.; Eilenberg, J.; Hajek, A.E.; Steinkraus, D.C. Biology, ecology and pest management potential of Entomophthorales. In Fungi as Biocontrol Agents. Progress, Problems and Potential; Butt, T.M., Jackson, C.W., Magan, N., Eds.; CABII Publishing: Oxon, UK, 2001; pp. 71-153. ISBN 0-85199-356-7.

19. De Castro, T.R.; Wekesa, V.W.; Moral, R.D.; Demetrio, C.G.B.; Delalibera, I.; Klingen, I. The effects of photoperiod and light intensity on the sporulation of brazilian and norwegian isolates of Neozygites floridana. J. Invertebr. Pathol. 2013, 114, 230-233. [CrossRef] [PubMed]

20. Klingen, I.; Holthe, M.P.; Westrum, K.; Suthaparan, A.; Torp, T. Effect of light quality and light-dark cycle on sporulation patterns of the mite pathogenic fungus Neozygites floridana (Neozygitales: Entomophthoromycota), a natural enemy of Tetranychus urticae. J. Invertebr. Pathol. 2016, 137, 43-48. [CrossRef] [PubMed]

21. Klingen, I.; Wærsted, G.; Westrum, K. Overwintering and prevalence of Neozygites floridana (Zygomycetes: Entomophthorales) in hibernating females of Tetranychus urticae (Acari: Tetranychidae) under cold climatic conditions in strawberries. Exp. Appl. Acarol. 2008, 46, 231-245. [CrossRef] [PubMed]

22. Duarte, V.S.; Westrum, K.; Ribeiro, A.E.L.; Gondim, M.G.C., Jr.; Klingen, I.; Delalibera, I., Jr. Abiotic and biotic factors affecting resting spore formation in the mite pathogen Neozygites floridana. Int. J. Microbiol. 2013, 2013, 276168. [CrossRef]

23. Wekesa, V.W.; Moraes, G.J.; Ortega, E.M.M.; Delalibera, I., Jr. Effect of temperature on sporulation of Neozygites floridana isolates from different climates and their virulence against the tomato red spider mite, Tetranychus evansi. J. Invertebr. Pathol. 2010, 103, 36-42. [CrossRef] [PubMed]

24. Shapiro-Ilan, D.I.; Bruck, D.J.; Lacey, L.A. Chapter 3-Principles of epizootiology and microbial control. In Insect Pathology, 2nd ed.; Kaya, H.K., Ed.; Academic Press: San Diego, CA, USA, 2012; pp. $29-72$. ISBN 978-0-12-384984-7.

25. Brown, G.C.; Hasibuan, R. Conidial discharge and transmission efficiency of Neozygites floridana, an entomopathogenic fungus infecting 2-spotted spider-mites under laboratory conditions. J. Invertebr. Pathol. 1995, 65, 10-16. [CrossRef]

26. Oduor, G.I.; Yaninek, J.S.; van der Geest, L.P.S.; de Moraes, G.J. Germination and viability of capilliconidia of Neozygites floridana (zygomycetes: Entomophthorales) under constant temperature, humidity, and light conditions. J. Invertebr. Pathol. 1996, 67, 267-278. [CrossRef] [PubMed]

27. Klingen, I.; Nilsen, S.S. Mechanisms important for the epidemic development of Neozygites floridana in Tetranychus urticae. IOBC WPRS Bull. 2009, 45, 287-289.

28. Boulard, T.; Fatnassi, H.; Roy, J.C.; Lagier, J.; Fargues, J.; Smits, N.; Rougier, M.; Jeannequin, B. Effect of greenhouse ventilation on humidity of inside air and in leaf boundary-layer. Agric. For. Meteorol. 2004, 125, 225-239. [CrossRef]

29. Fargues, J.; Vidal, C.; Smits, N.; Rougier, M.; Boulard, T.; Mermier, M.; Nicot, P.; Reich, P.; Jeannequin, B.; Ridray, G.; et al. Climatic factors on entomopathogenic hyphomycetes infection of Trialeurodes vaporariorum (homoptera: Aleyrodidae) in mediterranean glasshouse tomato. Biol. Control 2003, 28, 320-331. [CrossRef] 
30. Duarte, V.S. Studies for Implementation of Neozygites floridana as Control Agent of Two-Spotted Spider Mite in Strawberry; Escola Superior de Agricultura Luiz de Queiroz, Universidade de São Paulo: São Paulo, Brazil, 2013.

31. Solomon, M.E. Control of humidity with potassium hydroxide, sulphuric acid, or other solutions. Bull. Entomol. Res. 1951, 42, 543-554. [CrossRef]

32. McCullagh, P.; Nelder, J.A. Generalized Linear Models; Chapman and Halln: London, UK, 1989; 511p.

33. R Development Core Team. R: A Language and Environment for Statistical Computing, version 3.2.2; R Foundation for Statistical Computing: Vienna, Austria; Available online: http:/ /www.R-project.org/ (accessed on 5 February 2017).

34. Moral, R.A.; Hinde, J.; Demétrio, C.G.B. Half-normal plots and overdispersed models in R: The hnp package. J. Stat. Softw. 2017, 81, 23. [CrossRef]

35. Smitley, D.R.; Brooks, W.M.; Kennedy, G.G. Environmental effects on production of primary and secondary conidia, infection, and pathogenesis of Neozygites floridana, a pathogen of the twospotted spider mite, Tetranychus urticae. J. Invertebr. Pathol. 1986, 47, 325-332. [CrossRef]

36. Oduor, G.I.; de Moraes, G.J.; Van der Geest, L.P.S.; Yaninek, J.S. Production and germination of primary conidia of Neozygites floridana (zygomycetes: Entomophthorales) under constant temperatures, humidities, and photoperiods. J. Invertebr. Pathol. 1996, 68, 213-222. [CrossRef] [PubMed]

37. Oduor, G.I.; de Moraes, G.J.; Yaninek, J.S.; van der Geest, L.P.S. Effect of temperature, humidity and photoperiod on mortality of Mononychellus tanajoa (acari: Tetranychidae) infected by Neozygites cf floridana (zygomycetes: Entomophthorales). Exp. Appl. Acarol. 1995, 19, 571-579. [CrossRef]

38. Boulard, T.; Mermier, M.; Fargues, J.; Smits, N.; Rougier, M.; Roy, J.C. Tomato leaf boundary layer climate: Implications for microbiological whitefly control in greenhouses. Agric. For. Meteorol. 2002, 110, 159-176. [CrossRef]

(C) 2018 by the authors. Licensee MDPI, Basel, Switzerland. This article is an open access article distributed under the terms and conditions of the Creative Commons Attribution (CC BY) license (http://creativecommons.org/licenses/by/4.0/). 